\title{
Effect of Nitrogen Fertilization on Yields and Nitrogen Content of Cassava, Llanera Cultivar ${ }^{1,2}$
}

\author{
R. H. Fox, H. Talleyrand and T.W. Scott ${ }^{3}$
}

\begin{abstract}
Experiments were conducted on two Ultisols in the interior of Puerto Rico to determine the fertilizer $\mathrm{N}$ requirements of a high yielding, high root protein variety of cassava (Manihot esculenta Crantz cv. Llanera) from Colombia. This variety appeared to be daylength sensitive and top growth ceased from mid November to mid-February, when days were shorter than 111/2 hours. At Corozal (Humatas clay), the crop was grown from midMarch to mid-December and top growth responded strongly and root growth moderately to applied N. High $\mathrm{N}$ rates produced low root/top ratios (.67-.87) but, due to the experience at the Cidra site, it is assumed that root/top ratios would have increased to higher levels had the crop continued to grow. Apparent recovery of fertilizer N was high (68-69 percent) for the 40 and $80 \mathrm{~kg} / \mathrm{ha}$ rates. At Cidra (Torres clay), where the crop grew from mid-June until the following May and was dormant for the three winter months, there was no response to $\mathrm{N}$, the top yields were lower but the root/top ratios were higher (average, 1.37) and were not affected by $\mathrm{N}$ rates. The lack of response to $\mathrm{N}$ was due to the high $\mathrm{N}$ supplying power of this soil. The maximum root yields were 23 metric tons/ha at Corozal and 33 metric tons/ha at Cidra. Plants in the highest yielding treatments contained $125-175 \mathrm{~kg} / \mathrm{ha} \mathrm{N}$. Assuming all $\mathrm{N}$ was protein $\mathrm{N}$, unpeeled root protein contents averaged 3.4 percent and peeled 2.3 percent on a dry weight basis and were increased only slightly by higher $\mathrm{N}$ rates. The $\mathrm{N}$ content of the 4 th and 5th fully expanded leaves $4-5$ months after planting was very well correlated with final root yield at Corozal $\left(R^{2}=.99\right.$ for $0-160 \mathrm{~kg} / \mathrm{ha}$ $N$ rates). It appears that a minimum of 5 percent $N$ in these leaves $21 / 2$ months after planting is necessary for maximum yields.
\end{abstract}

1 Manuscript submitted to Editorial Board. October 16, 1974.

2 Joint contribution from the Department of Agronomy, Cornell University, Ithaca, New York as Agronomy Paper No. 2001 and the Agricultural Experiment Station, University of Puerto Rico, Mayaguez Campus, Rio Piedras, Puerto Rico. This study was part of the investigations supported by the USAID under research contract ta-c-1104 entitled: "Soil Fertility in the Humid Tropics."

${ }^{3}$ Assistant Professor of Soil Science, Research Technician, and Professor of Soil Science, Cornell University, respectively. The senior author is presently Assistant Professor of Soil Science, Pennsylvania State University. 


\section{INTRODUCTION}

A variety of cassava, Llanera, has been found in Colombia with a reported maximum yield of 78 tons/ha in 10 months and a protein content three times that of the average sweet cassava variety (2). The possibility of obtaining very high yields and significantly increasing the notoriously low protein content of this major food staple of the humid tropics makes this a very attractive variety to study. An experiment was conducted to determine if similar yields and protein contents could be obtained in Puerto Rico with Llanera and what levels of fertilizer $N$ would be necessary for maximum yields. Leaves and petioles were sampled to determine if their $\mathrm{N}$ content could be correlated with yields and $\mathrm{N}$ uptake.

Literature reviews $(1,4)$ indicate that applications of $N, P$, and $K$ are necessary for high cassava yields. The recommended rate of $\mathrm{N}$, however, is generally fairly low (12-80 kg/ha) (4), as would be expected for a long

TABLE 1.-Selected chemical properties of soils used in $N$ experiments

\begin{tabular}{|c|c|c|c|c|c|c|c|c|c|c|}
\hline \multirow{2}{*}{ Soil } & \multirow{2}{*}{ Depth } & \multirow{2}{*}{$\mathbf{O M}$} & \multirow{2}{*}{$\mathbf{N}$} & \multirow{2}{*}{ pH } & \multirow{2}{*}{$\begin{array}{l}\mathrm{CEC} \\
\text { (NHA. } \\
\mathrm{OAc})\end{array}$} & \multirow{2}{*}{ Cations } & \multicolumn{4}{|c|}{ Exchangeable Cations } \\
\hline & & & & & & & $\mathrm{Ca}^{++}$ & $\mathrm{Mg}^{++}$ & $\mathbf{K}^{+}$ & Al+++ \\
\hline & $\mathrm{Cm}_{m}$ & Percent & Percent & & \multicolumn{6}{|c|}{$M$ eq/100 g } \\
\hline $\begin{array}{l}\text { Humatas (Typic Tropo- } \\
\text { humult; clayey, mixed, } \\
\text { isohyperthermic) }\end{array}$ & $\begin{array}{r}0-25 \\
25-50\end{array}$ & $\begin{array}{l}3.7 \\
1.2\end{array}$ & 0.17 & $\begin{array}{l}5.0 \\
4.6\end{array}$ & $\begin{array}{l}17.0 \\
13.6\end{array}$ & $\begin{array}{r}7.9 \\
12.4\end{array}$ & $\begin{array}{l}6.4 \\
3.0\end{array}$ & $\mid \begin{array}{l}0.8 \\
0.8\end{array}$ & & $\begin{array}{l}0.0 \\
8.4\end{array}$ \\
\hline $\begin{array}{l}\text { Torres (Orthoxic Tropu- } \\
\text { dult; clayey, mixed, } \\
\text { isohyperthermic) }\end{array}$ & $\begin{array}{r}0-25 \\
25-50\end{array}$ & $\begin{array}{l}3.6 \\
0.9\end{array}$ & 0.23 & $\begin{array}{l}4.7 \\
4.8\end{array}$ & $\begin{array}{c}13 . \\
9.80\end{array}$ & $\begin{array}{l}7.4 \\
6.8\end{array}$ & $\begin{array}{l}5.6 \\
2.0\end{array}$ & $\begin{array}{l}1.2 \\
0.4\end{array}$ & $\begin{array}{l}0.4 \\
0.4\end{array}$ & $\begin{array}{l}0.2 \\
4.0\end{array}$ \\
\hline
\end{tabular}

growing, low $\mathrm{N}$ content crop [0.35 percent $\mathrm{N}$ in storage root dry matter (1)]. In some instances, when either the yields were low (7) or the cassava was allowed to grow for 18-21 months $(5,6)$, there was no response to fertilizer N. Presumably, Llanera with its high yields and protein content would require higher rates of $\mathrm{N}$ for maximum yield than do other varieties reported in the literature.

\section{MATERIALS AND METHODS}

The experimental sites were at the Corozal Substation on Humatas soil (Typic Tropohumult, clayey, mixed isohyperthermic) and on a private farm near Cidra on Torres soil (Orthoxic Tropudult, clayey, mixed, isohyperthermic), both having been used previously for $\mathrm{N}$ fertility experiments with corn and sorghum, begun in 1970 at Corozal and 1971 at Cidra. Prior to this, both sites had been in fertilized pastures. The Corozal site is $250 \mathrm{~m}$ above sea level and that at Cidra $450 \mathrm{~m}$. Table 1 lists selected chemical properties of the two soils. 
A blanket application of $66 \mathrm{~kg} / \mathrm{ha} \mathrm{P}$ as triple superphosphate, $125 \mathrm{~kg} / \mathrm{ha}$ $\mathrm{K}$ as $\mathrm{K}_{2} \mathrm{SO}_{4}, 50 \mathrm{~kg} / \mathrm{ha} \mathrm{Mg}$ as $\mathrm{MgSO}_{4} \cdot 7 \mathrm{H}_{2} \mathrm{O}$ and $5 \mathrm{~kg} / \mathrm{ha} \mathrm{Zn}$ as $\mathrm{ZnSO}_{4} \cdot 7-$ $\mathrm{H}_{2} \mathrm{O}$ were disked into the soil prior to planting. A sidedress of $125 \mathrm{~kg} / \mathrm{ha} \mathrm{K}$ and $50 \mathrm{~kg} / \mathrm{ha} \mathrm{Mg}$ was applied 3 months after planting.

The treatments at both sites were $0,40,80,120,160$ and $200 \mathrm{~kg} / \mathrm{ha} \mathrm{N}$ as urea and $120 \mathrm{~kg} / \mathrm{ha} \mathrm{N}$ as sulfur coated urea (dissolution rate of 21.5 percent in 7 days). One fourth of the fertilizer was broadcast and disked in at planting and $3 / 4$ applied 3 months later in a band $30 \mathrm{~cm}$ to the side of the row and $7 \mathrm{~cm}$ below the soil surface. An additional treatment was used at Corozal in which $120 \mathrm{~kg} / \mathrm{ha} \mathrm{N}$ as urea was applied $1 / 4$ at planting, $1 / 2$ at 3 months and $1 / 4,6$ months after planting. There were 5 replications in a randomized block design, with plots of $4.9 \times 9.8 \mathrm{~m}$.

Ten to $20 \mathrm{~cm}$ sections of stalks were placed horizontally every $90 \mathrm{~cm}$ in rows $90 \mathrm{~cm}$ apart and covered with 2 to $5 \mathrm{~cm}$ of soil. The Corozal site was planted on March 16, and the Cidra site on June 14, 1973. Ungerminated seed pieces were replaced with new seed pieces 2 to 3 weeks later.

Soil insects and nematodes were controlled by an application of 112 $\mathrm{kg} / \mathrm{ha}$ of Dasanit disked in with the blanket fertilizer. Weeds were kept under control by hand weeding every 3 to 4 weeks until the crop was tall and dense enough to shade out competing weeds. Diazinon and Malathion were applied alternately at biweekly intervals during the first four months after planting in order to minimize tip fly (Silba pendula) damage.

A mite (Tetranychus sp.) problem developed in a portion of the Corozal field when the plants were approximately 5 months old. This was controlled by spraying with Kelthane. Later, slight infestations could not be sprayed since the cassava stems were so intercrossed that the field could not be entered without breaking many stems and causing more damage than the mites.

The fourth and fifth fully expanded leaves and petioles from eight stems on each plot were analyzed for total $\mathrm{N}$ and the petioles for $\mathrm{NO}_{3}^{-}$and total N.

Eight meters of the two center rows of each plot were harvested on December 17-19, 1973, at Corozal. At Cidra, $7 \mathrm{~m}$ were harvested from the two center rows of each plot on May 17 and 18, 1974. Roots and tops were weighed and subsamples taken for moisture and $\mathrm{N}$ contents.

\section{RESULTS AND DISCUSSION}

\section{GROWTH}

There was a severe drought during the spring and early summer of 1973. At Corozal, irrigation was provided during the first few months, but at Cidra, with no irrigation facilities, an earlier planting in May had to be completely replanted in June because of the poor germination. 
Once established the cassava grew very well at both sites. At Corozal, the $\mathrm{N}$ fertilized, March-planted cassava was $2 \mathrm{~m}$ high in September and had a high leaf area index that shaded out all weed growth. With adequate rainfall occurring at Cidra in August, the June-planted cassava began to grow vigorously, had dense foliage and was approximately $1.5 \mathrm{~m}$ high by mid-November.

Top growth ceased in mid-November at both sites. At Corozal, growth might have stopped normally since the plants were 8 months old and quite large, but at Cidra they were only 5 months old and were not as tall as the Corozal plants. (At a third site between Naranjito and Barranquitas, abandoned later because of the drought-induced poor growth and severe weed infestation, the plants were only 60 to $80 \mathrm{~cm}$ high when top growth ceased.) There was some flowering after cessation of leaf growth and after approximately one month, the older leaves began to drop off. The plants were harvested in December at Corozal but at Cidra and Barranquitas, where the plants were left in the field, almost all leaves had dropped off by January. New top growth began in mid-February and the plants at Cidra were growing vigorously when they were harvested in mid-May.

This indicates that Llanera cassava is day-length sensitive and does not grow when days are shorter than 111/2 hours. This would have been no problem in Colombia, where day-length is never less than this, except at the most northern latitudes.

\section{YIELD AND N RESPONSE}

The Humatas soil at the Corozal site has a fairly low $\mathrm{N}$ supplying power and large responses to $\mathrm{N}$ have occurred on this soil with corn and sorghum (3). The cassava plants on the plots receiving no $N$ were a paler green and slightly smaller than the rest three and a half months after planting. By five and a half months after planting, the check plants were considerably shorter and paler than the high $\mathrm{N}$ treatments and plants in the lower two $\mathrm{N}$ level plots were slightly smaller and paler than the high $\mathrm{N}$ treatments. Leaf $\mathrm{N}$ contents, discussed in a later section, were also lower in the zero and low $\mathrm{N}$ treatments, indicating that the growth was limited by $\mathrm{N}$ supply.

The maximum storage root yield at Corozal was only 23 metric tons/ha in 9 months (table 2), considerably less than the 78 metric tons/ha reported for this variety in Colombia (2). The three highest rates of $\mathrm{N}, 120$, 160 and $200 \mathrm{~kg} / \mathrm{ha}$ produced yields significantly higher than the 15.1 metric tons/ha in the zero $N$ treatment. There was a much more pronounced yield response to $\mathrm{N}$ by the stems plus leaves than by the roots. Yields ranged from 10.5 tons/ha with no $\mathrm{N}$ to 30.3 tons/ha with $200 \mathrm{~kg} / \mathrm{ha} \mathrm{N}$. The question arises, would storage root growth have continued had the plants not stopped growing because of the short day-length? If the storage 
roots had continued to grow, yields of over 30 metric tons/ha might have been obtained and the $\mathrm{N}$ response have been considerably different than was observed in this experiment.

Results from the sulfur coated urea and double split application were not significantly different from those of the same rate of standard applied urea N. Furthermore, the double split had the disadvantage that many stems were broken when the field was entered for the $\mathrm{N}$ application six months after planting.

TABLE 2.-Cassava yields and $N$ contents as a function of fertilizer $N$ applied, Corozal

\begin{tabular}{|c|c|c|c|c|c|c|c|c|c|}
\hline \multirow{2}{*}{$\mathbf{N}$ applied' } & \multicolumn{2}{|c|}{ Yield ${ }^{2}$} & \multirow{2}{*}{$\begin{array}{c}\text { Root/top } \\
\text { ratio }\end{array}$} & \multirow{2}{*}{$\begin{array}{c}\text { Root } \\
\text { proteins }\end{array}$} & \multirow{2}{*}{ Root N } & \multirow{2}{*}{ Stem $\mathbf{N}$} & \multirow{2}{*}{ Leaf $\mathbf{N}$} & \multirow{2}{*}{ Total N } & \multirow{2}{*}{$\begin{array}{l}\text { Apparent } \\
\text { N recovery }\end{array}$} \\
\hline & $\begin{array}{c}\text { Storage } \\
\text { root }\end{array}$ & $\underset{\text { leaf }}{\text { Stem and }}$ & & & & & & & \\
\hline$K_{8} / h a$ & \multicolumn{2}{|c|}{ Tons/ha } & & Percent & \multicolumn{4}{|c|}{$\boldsymbol{K}_{\boldsymbol{g}} / h_{\boldsymbol{G}}$} & Percent \\
\hline 0 & $15.1 b^{6}$ & $10.5 \mathrm{~d}$ & 1.43 & $3.0 \mathrm{~b}$ & $23 \mathrm{~b}$ & $31 \mathrm{~d}$ & $16 \mathrm{~b}$ & $70 \mathrm{~d}$ & - \\
\hline 40 & $19.5 \mathrm{ab}$ & $18.7 \mathrm{c}$ & 1.04 & $2.9 \mathrm{~b}$ & $29 a b$ & $50 \mathrm{c}$ & $18 \mathrm{~b}$ & $97 \mathrm{~cd}$ & 68 \\
\hline 80 & $19.8 \mathrm{ab}$ & $22.2 \mathrm{bc}$ & .89 & $3.6 \mathrm{ab}$ & 35 a & $58 \mathrm{bc}$ & $32 \mathrm{~b}$ & $125 \mathrm{bc}$ & 69 \\
\hline 120 & $22.3 a$ & $22.1 \mathrm{bc}$ & 1.00 & $3.3 \mathrm{ab}$ & $35 \mathrm{a}$ & $64 \mathrm{bc}$ & $27 \mathrm{~b}$ & $126 \mathrm{bc}$ & 47 \\
\hline 160 & $23.0 \mathrm{a}$ & $26.3 \mathrm{ab}$ & .87 & $3.2 \mathrm{ab}$ & 35 a & $75 \mathrm{~b}$ & $28 \mathrm{~b}$ & $138 \mathrm{~b}$ & 43 \\
\hline 200 & $20.4 \mathrm{a}$ & 30.3 a & .67 & $4.3 \mathrm{a}$ & $41 \mathrm{a}$ & 96 a & $49 \mathrm{a}$ & $186 \mathrm{a}$ & 58 \\
\hline $120 \mathrm{SCU}$ & $18.8 \mathrm{ab}$ & $22.0 \mathrm{bc}$ & .85 & $3.9 \mathrm{ab}$ & $35 \mathrm{a}$ & $64 \mathrm{bc}$ & $21 \mathrm{~b}$ & $120 \mathrm{bc}$ & 42 \\
\hline $120 \mathrm{TS}$ & $22.4 \mathrm{a}$ & $25.6 \mathrm{ab}$ & .88 & $3.6 \mathrm{ab}$ & $41 \mathrm{a}$ & $75 \mathrm{~b}$ & $32 \mathrm{~b}$ & $148 \mathrm{~b}$ & 65 \\
\hline
\end{tabular}

134 applied at planting; $\$ / 4,3$ months later, SCU (sulphur coated urea), with a dissolution rate of 21.5 percent in 7 days. TS had $1 / 4$ applied at planting; 1/2 at 3 months; and 34 at 6 months.

${ }^{2}$ Root and top yield are fresh weight. Both were 30 to 32 percent dry matter.

${ }^{3}$ Root $\mathrm{N}$ content $\times 6.25$.

4 (Total $\mathrm{N}$ of fertilized treatment minus total $\mathrm{N}$ of $\mathrm{O}-\mathrm{N}$ treatment)/N applied to treatment.

5 Values followed by the same letter in a vertical column are not statistically different at the 5-percent probability level using Duncan's Multiple Range Test.

The Torres soil has a much higher $\mathrm{N}$ supplying power and no $\mathrm{N}$ response had been obtained with two corn crops grown there prior to this crop (3). There was no visible difference among the treatments in top growth or in leaf $\mathrm{N}$ contents with the cassava. The average storage root yield was 31.6 metric tons/ha with no yield response to $\mathrm{N}$ by roots or tops (table 3 ). Active growth had occurred during approximately 8 of the 11 months since. planting. The average root/top ratio of 1.37, with a range from 1.25 to 1.48, was quite different from that in Corozal, where it ranged from 1.43 with no $\mathrm{N}$ down to 0.67 with $200 \mathrm{~kg} / \mathrm{ha} \mathrm{N}$. This indicates that either the root yields in Corozal would have been considerably higher had the plants been able to grow for a few months more if there had been the same average 
root/top ratio of 1.37 at Corozal as at Cidra, (the 30.3 tons/ha stems and leaves obtained with $200 \mathrm{~kg} / \mathrm{ha}$ would have resulted in $41.5 \mathrm{tons} / \mathrm{ha}$ of roots) or that the top growth stoppage during the short days at Cidra resulted in a much higher proportion of the photosynthate transferred to the storage roots than is normal. The low root/top ratio with high $\mathrm{N}$ rates at Corozal cannot be attributed solely to too high $\mathrm{N}$ levels since the even higher levels of $N$ (soil $N$ plus fertilizer $N$ ) at Cidra produced high root/top ratios. Further experimentation will be necessary to determine the effect

TABLE 3.-Cassava yields and $N$ contents as a function of fertilizer $N$ applied, Cidra

\begin{tabular}{|c|c|c|c|c|c|c|c|c|c|}
\hline \multirow{2}{*}{$\mathrm{N}$ applied ${ }^{1}$} & \multicolumn{2}{|c|}{ Yield2 } & \multirow{2}{*}{$\begin{array}{c}\text { Root/top } \\
\text { retio }\end{array}$} & \multirow{2}{*}{$\begin{array}{c}\text { Root } \\
\text { protein" }\end{array}$} & \multirow{2}{*}{ Root N } & \multirow{2}{*}{ Stem N } & \multirow{2}{*}{ Leaf $\mathbf{N}$} & \multirow{2}{*}{ Total N } & \multirow{2}{*}{$\begin{array}{l}\text { Apparent } \\
\text { N re- } \\
\text { covery }\end{array}$} \\
\hline & $\begin{array}{c}\text { Storage } \\
\text { root }\end{array}$ & $\begin{array}{c}\text { Stem and } \\
\text { leaf }\end{array}$ & & & & & & & \\
\hline & \multicolumn{2}{|c|}{ Tons/he } & & Percent & \multicolumn{4}{|c|}{$K_{\mathbf{g}} / k a$} & Percent \\
\hline 0 & 31.7 & 24.8 & 1.27 & 3.0 & 53 & 61 & 35 & 149 & - \\
\hline 40 & 32.0 & 22.1 & 1.44 & 3.0 & 58 & 57 & 32 & 147 & - \\
\hline 80 & 31.5 & 24.4 & 1.29 & 3.0 & 54 & 66 & 37 & 157 & 10 \\
\hline 120 & 33.0 & 22.7 & 1.45 & 3.5 & 64 & 65 & 35 & 164 & 13 \\
\hline 160 & 31.5 & 25.1 & 1.25 & 3.9 & 67 & 72 & 38 & 177 & 18 \\
\hline 200 & 31.9 & 21.6 & 1.48 & 3.7 & 64 & 69 & 33 & 166 & 9 \\
\hline $120 \mathrm{SCU}$ & 28.6 & 20.3 & 1.41 & 3.4 & 54 & 53 & 31 & 138 & - \\
\hline \multirow{2}{*}{ Avg. } & 31.6 & 22.9 & 1.37 & 3.4 & 60 & 63 & 34 & 157 & - \\
\hline & NSD $^{3}$ & NSD & NSD & NSD & NSD & NSD & NSD & NSD & \\
\hline
\end{tabular}

1 1/4 applied at planting; $1 / 4,3$ months later, SCU (sulphur costed urea), with a dissolution rate of 21.5 percent in 7 days.

2 Root and top yield are fresh weight. Both were 30 to 32 percent dry matter.

Root $\mathrm{N}$ content $\times 6.25$.

(Total $\mathrm{N}$ of fertilized treatment minus total $\mathrm{N}$ of $\mathrm{O}-\mathrm{N}$ treatment)/N applied to treatment.

- No significant differences.

of day-length and length of growing period on the relationship between root/top ratios and $\mathrm{N}$ fertilization with this cassava variety.

The roots were extremely difficult to harvest at both sites since they were in heavy clay soils and grew to depths of 15 to $30 \mathrm{~cm}$. It was calculated that at Corozal (the more difficult site), hand harvesting would require at least 1,424 man-hours/ha (576 man-hours/acre). Unless a better system of harvesting or planting is used it is highly unlikely that this crop could be produced economically on these soils. Planting in ridges would probably make harvesting considerably easier.

The storage roots at Cidra were attacked fairly severely by white grubs (Diaprepes abbreviatus) and secondarily by slugs (Veronicella cubensis). It would be interesting to determine if the insect problem would have developed had the plants not been dormant for 3 months. 
The eating quality of Llanera was judged excellent and very little fiber had formed even in the 11-month old storage roots at Cidra.

\section{N CONTENT}

At Corozal the total plant $\mathrm{N}$ contents were positively correlated with the quantity of $N$ applied (table 2) and ranged from $70 \mathrm{~kg} / \mathrm{ha}$ with no fertilizer $\mathrm{N}$ to $186 \mathrm{~kg} / \mathrm{ha}$ with $200 \mathrm{~kg} / \mathrm{ha} \mathrm{N}$ applied. The apparent fertilizer $\mathrm{N}$ recovery was a high 68 and 69 percent for the 40 and $80 \mathrm{~kg} / \mathrm{ha} \mathrm{N}$ levels. Higher rates resulted in lower recoveries but, again, the recovery might have been higher had the plants been able to grow a few more months until a higher root/top ratio was obtained. The recovery of SCU-N was approximately the same as from the same rate of urea. The double split application resulted in considerably higher fertilizer $\mathrm{N}$ recovery but, as mentioned earlier, the difficulty in entering the field without causing serious damage to the plants when they are 6 months old makes this application method impractical.

The plant $\mathrm{N}$ contents at Cidra ranged from 138 to $177 \mathrm{~kg} / \mathrm{ha}$ with no significant difference among $\mathrm{N}$ treatments (table 3 ). The fertilizer $\mathrm{N}$ recovery was, of course, very low under these conditions.

Assuming that all the root $\mathrm{N}$ was protein, unpeeled storage root protein content at the two sites ranged from 2.91 to 4.31 percent on a dry matter basis, considerably below the 6.4 percent reported for Llanera in Colombia. The peeled roots contained only an average of 2.3 percent protein, which is not much higher than that reported in the literature for other varieties of sweet cassava (1). Higher rates of fertilizer $N$ increased the root protein content but did so erratically.

\section{LEAF N CONTENTS}

Leaves were sampled at Corozal one and two and a half months after the post plant sidedress fertilizer $\mathrm{N}$ application. The selection of the fourth and fifth fully expanded leaves was arbitrary since, to our knowledge, no standard method is recorded in the literature. Analysis of a few plants showed that, as expected, younger leaves have more and older leaves less $\mathrm{N}$ than the test leaves.

In the first sampling, petiole $\mathrm{NO}_{3}-$ and total $\mathrm{N}$ were also analyzed. The $\mathrm{NO}_{3}-$ values were generally positively correlated with $\mathrm{N}$ applied but were too erratic to use. For example, individual values within a treatment ranged from 500 to $3000 \mathrm{p} / \mathrm{m}$. Since the petiole total $\mathrm{N}$ content was not as well correlated with $\mathrm{N}$ applied as leaf $\mathrm{N}$, it was decided to use leaf $\mathrm{N}$ contents as an index of plant $\mathrm{N}$ status.

Leaf $\mathrm{N}$ was highly correlated with $\mathrm{N}$ applied for both sampling dates (fig. 1). Linear and quadratic regression analysis demonstrated that the leaf $\mathrm{N}$ contents for both dates were significantly correlated with root and 
top yields and their $\mathrm{N}$ contents. The correlation between leaf $\mathrm{N}$ content at the one and two and a half month sampling dates and root weight of the first 5 rates of $N(0-160 \mathrm{~kg} / \mathrm{ha} N)$ was exceptionally good $\left(R^{2}=.99\right)$. However, the practical value of these correlations is limited since there was no significant difference in root yield among any of the treatments that received fertilizer $\mathrm{N}$. It does appear, though, that the 4th and 5th fully expanded leaves must contain at least 5.0 percent $\mathrm{N}$ one to two months after

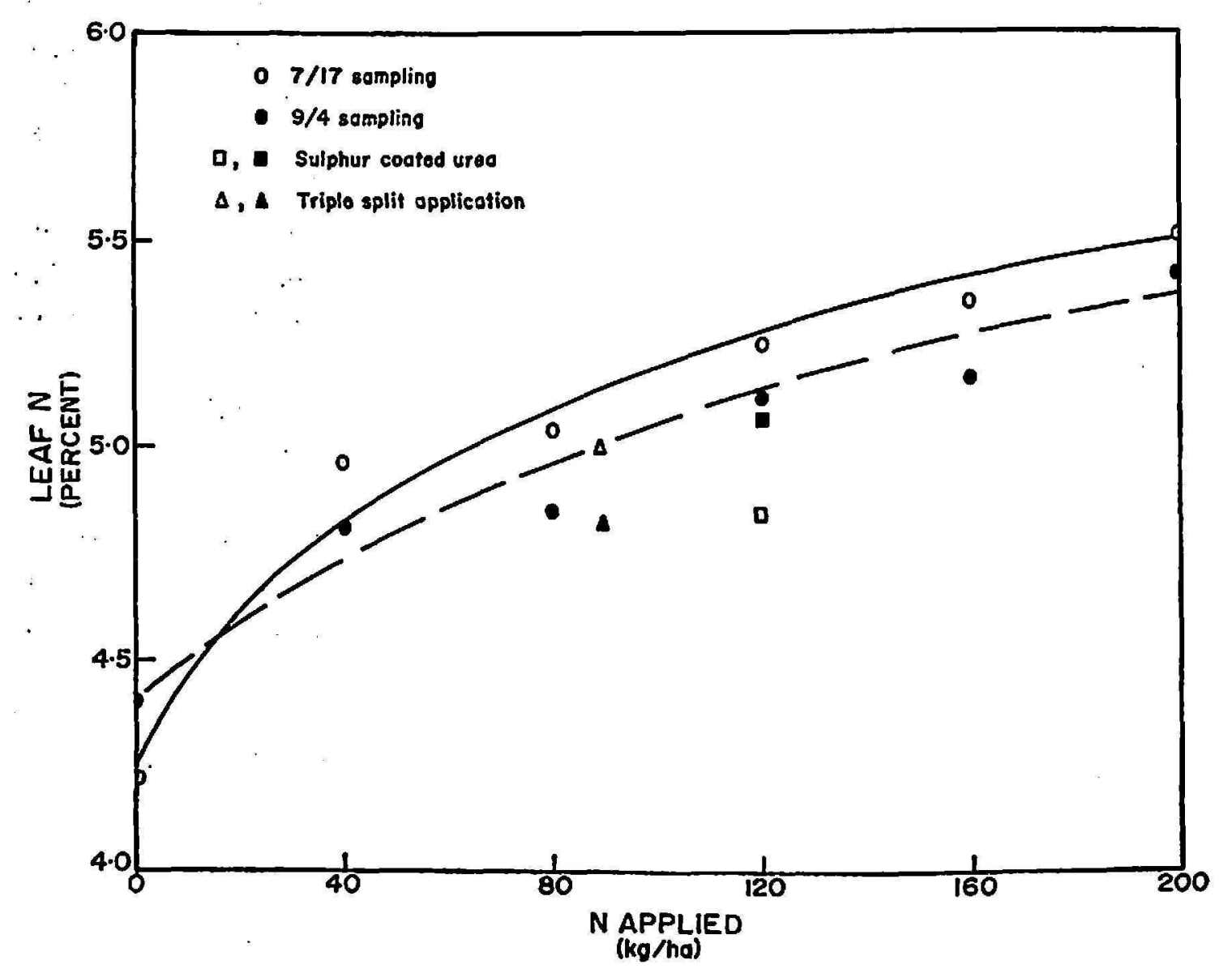

Fra. 1.-Cassava leaf $\mathbf{N}$ content at Corozal as a function of fertilizer $\mathbf{N}$ applied.

the sidedress $\mathrm{N}$ application (4 to 5 months after planting) to obtain maximum root yields.

At Cidra, leaves were sampled at the time of the post plant $N$ application and again 50 days later. The leaf $\mathrm{N}$ contents for the first sampling ranged from 5.31 to 5.61 percent with no significant correlation with $\mathrm{N}$ applied. In the sampling 50 days after the post plant $\mathrm{N}$ applications, the leaf $\mathrm{N}$ content ranged from 5.4 to 6.02 percent and the only relationship with fertilizer $\mathrm{N}$ applied was that the lowest $\mathrm{N}$ content was in the $0 \mathrm{~N}$ treatment.

The over 5 percent leaf $\mathrm{N}$ in this variety is higher than in most leguminous crops and if the $\mathrm{N}$ is all protein the leaves contain more than 30 percent protein. 


\section{CONCLUSIONS}

Llanera cassava appears to be day-length sensitive and does not grow in Puerto Rico between mid-November and mid-February when the days are shorter than 111/2 hours. This growth stoppage confounded the results of the $\mathrm{N}$ trials since root yields and root/top ratios appeared to depend on the time of planting and length of growing period. At Corozal, where the cassava grew eight uninterrupted months and was harvested at 9 months in mid-December, high $\mathrm{N}$ levels produced luxuriant top growth but low root/ top ratios and a maximum root yield of 23 tons/ha. At Cidra, where the cassava was not planted until June, remained dormant for the 3 winter months, and was not harvested until the following May, eleven months after planting, there were high root/top ratios which were not affected by $\mathrm{N}$ rates and a maximum storage root yield of 33 tons/ha. It does not appear that yields of 78 tons/ha as reported for Colombia are possible in Puerto Rico but yields of 40 tons/ha are probably within reach in heavy clay soils if cassava is planted in February and irrigated.

There was a marked top growth and moderate root yield response to $\mathrm{N}$ at Corozal but no response at Cidra. The lack of response at Cidra is due to the high $N$ supplying power of this soil which had been in fertilized pasture until 1971. The soil at Corozal is, however, probably more representative of the continuously cultivated mountain soils of Puerto Rico. At both sites, maximum crop yields contained approximately $120-160 \mathrm{~kg} / \mathrm{ha} \mathrm{N}$. Apparent fertilizer $N$ recoveries at Corozal were a very high 68 to 69 percent for the lower rates of fertilizer N. Further study is necessary to determine the effect of planting and harvesting dates on the interaction between $\mathrm{N}$ rates and root yield.

SCU did not appear to offer any advantage over urea in increasing yield or $\mathrm{N}$ recovery.

Leaf $\mathrm{N}$ content proved to be an accurate indicator of plant $\mathrm{N}$ status. At Corozal, where there was a response to $\mathrm{N}$, there was an extremely good correlation between leaf $\mathrm{N}$ content 4 to 5 months after planting and final root yield $\left(R^{2}=.99\right)$ for the rates of $0-160 \mathrm{~kg} / \mathrm{ha} \mathrm{N}$. Results from these experiments indicate that a minimum of 5 percent $N$ in the 4th and 5 th fully expanded leaves $21 / 2$ months after planting is necessary for maximum root yields.

Root protein contents were only slightly more than half those reported for Llanera in Colombia.

It should be emphasized that further experimentation is necessary to determine why this Colombian variety performed so poorly in Puerto Rico. While it appears that day-length was an important factor, other climatic factors such as temperature may have also affected the yield potential and $\mathrm{N}$ content. 


\section{RESUMEN}

En dos suelos Ultisol, localizados en el interior de Puerto Rico, se llevaron a cabo experimentos para determinar los requisitos de nitrógeno del cultivar Llanera de yuca (Manihot esculenta Crantz) rica en proteina y oriunda de Colombia, América del Sur. Este cultivar parece ser sensitivo a las horas luz, pues el crecimiento vegetativo cesó de mediados de noviembre a mediados de febrero, cuando los dias eran de menos de 1136 horas. En Corozal, en un suelo Humatas, de mediados de marzo a mediados de diciembre el crecimiento vegetativo respondió marcadamente a aplicaciones de nitrógeno, mientras que el desarrollo de raices respondió moderadamente a estas aplicaciones. Aplicaciones elevadas de nitrógeno indujeron una baja proporción de raíces a follaje (.67 a .87), pero tomando en cuenta lo observado en el experimento sembrado en Cidra, se presume que la proporción de raices a follaje hubiese aumentado si la plantación hubiese continuado creciendo. La aparente recuperación del nitrógeno fue elevada (de 68 a 69 por ciento) cuando éste se aplicó a razón de 40 y $80 \mathrm{Kg} / \mathrm{Ha}$.

En Cidra, en una arcilla Torres, donde la plantación se desarrolló de mediados de junio al siguiente mes de mayo y que permaneció latente durante los tres meses de invierno, no hubo respuesta al nitrógeno; el rendimiento de tallos y hojas fué mas bajo, pero la proporción de raices a follaje fue más elevada (1.37, como promedio) y no fue afectada por las cantidades aplicadas de nitrógeno. La falta de respuesta a las aplicaciones de nitrógeno se deben a la riqueza de nitrógeno asimilable de dicho suelo. El rendimiento máximo de raices fue de $23 \mathrm{Tm}$./Ha. en Corozal y de 33 en Cidra. Las plantas en los tratamientos de rendimiento más elevado extrajeron de 125 a 175 kilogramos de nitrógeno por hectare. Presumiendo que todo el nitrógeno fuese proteico, las raices sin pelar contenian un promedio de 3.4 por ciento y las peladas 2.3 por ciento, a base de peso seco. El contenido en nitrógeno aumentó ligeramente cuando se aplicaron cantidades más elevadas de nitrógeno.

El contenido en nitrógeno de las cuarta y quinta hojas, tomadas al mes y a los dos meses y medio después de la siembra, correlacionó muy bien con el rendimiento de raices en Corozal ( $R^{2}=.99$ en las aplicaciones de 0 a $160 \mathrm{Kg}$./ Ha.). Al parecer las hojas de este cultivar deben tener no menos de 5 por ciento de nitrógeno a los $2 \frac{1}{2}$ meses después de sembrado para lograr rendimientos máximos.

\section{LITERATURE CITED}

1. A Literature Review and Research Recommendations on Cassava, Univ. of Georgia, Athens, Ga., 1972.

2. Estrada Ramos, N., Colombian studies for the improvement of Manihot esculenta culture, Proc. 2nd. Intl. Symp. Trop. Root Crops, 1: 83, 1970.

3. Fox, R. H., Talleyrand, H., and Bouldin, D. R., Nitrogen fertilization of corn and sorghum grown in Oxisols and Ultisols in Puerto Rico, Agron. J., 66: 534-540, 1974.

4. Jacoby, T., Nutrition and manuring of tropical root crops, Green Bull. 19, Velagsgesellschaft für Acherban MBH Hannover, 1965.

5. Normanha, E. S., Pereira, H. S., and Freire, E. S., Modo e época de aplição de adubos minerais em cultura de mandioca, Bragantia $27: 143-54,1968$.

6. Ribeiro da Silva, J., and Freire, E. S., Efeito de doses crescentes de nitrogénio, fósforo e potassio sobre a produção de mandioca em solos de baixa e alta fertilidade, Bragantia $27:$ 357-364, 1968.

7. Samuels, G., The influence of fertilizer levels and sources on cassava production on Lares clay in Puerto Rico, Carib. Food Crop Soc. VII 33-35, 1969. 